\title{
Author Correction: Distinct effects of social motivation on face evaluations in adolescents with and without autism
}

\author{
Lou Safra $\mathbb{1}^{1}$, Christina loannou ${ }^{1}$, Frédérique Amsellem ${ }^{2,3}$, Richard Delorme ${ }^{2,3} \&$ \\ Coralie Chevallier ${ }^{1}$
}

Correction to: Scientific Reports https://doi.org/10.1038/s41598-018-28514-7, published online 13 July 2018

The Acknowledgements section in this Article is incomplete.

“This study was supported by the Institut d'Études Cognitives (ANR-10-LABX-0087 IEC and ANR10-IDEX-0001-02 PSL*). We are also grateful to Dr. Bahador Bahrami for providing us the stimuli.”

should read:

"This study was supported by Frontiers in Cognition (FrontCog, ANR-17-EURE-0017). We are also grateful to Dr. Bahador Bahrami for providing us the stimuli and to Raphael Delage for his valuable help in data collection."

(c) (i) Open Access This article is licensed under a Creative Commons Attribution 4.0 International License, which permits use, sharing, adaptation, distribution and reproduction in any medium or format, as long as you give appropriate credit to the original author(s) and the source, provide a link to the Creative Commons license, and indicate if changes were made. The images or other third party material in this article are included in the article's Creative Commons license, unless indicated otherwise in a credit line to the material. If material is not included in the article's Creative Commons license and your intended use is not permitted by statutory regulation or exceeds the permitted use, you will need to obtain permission directly from the copyright holder. To view a copy of this license, visit http://creativecommons.org/licenses/by/4.0/.

(C) The Author(s) 2018

${ }^{1}$ Laboratoire de Neurosciences Cognitives, Inserm unit 960, Département d'Etudes Cognitives, Ecole Normale Supérieure, PSL Research University, Paris, 75005, France. 'Service de Psychiatrie de l'Enfant et de l'Adolescent, Hôpital Universitaire Robert Debré, Paris, 75019, France. ${ }^{3}$ Génétique Humaine et Fonction Cognitive, Institut Pasteur, Paris, 75015, France. Correspondence and requests for materials should be addressed to L.S. (email: lou. safra@gmail.com) or C.C. (email: coralie.chevallier@ens.fr) 